\title{
American oyster (Crassostrea virginica) and sediments as a coastal zone pollution monitor by heavy metals
}

\author{
C. A. Aguilar $\cdot$ C. Montalvo $\cdot$ L. Rodríguez $\cdot$ \\ J. G. Cerón · R. M. Cerón
}

Received: 10 February 2011/ Accepted: 18 October 2011/Published online: 1 June 2012

(C) The Author(s) 2012. This article is published with open access at Springerlink.com

\begin{abstract}
Levels of barium, cadmium, chromium, copper, mercury and vanadium were determined by plasma emission spectroscopy in sediments and oysters (Crassostrea virginica) in the Palizada, Chumpán and Candelaria rivers, which flow into the Términos Lagoon, state of Campeche, Mexico. The relation between the condition index of the oyster and the detected elements were determined as well. Significant relations were observed between copper $(r=$ $-0.825, p<0.05)$ and chromium $(r=-0.787, p<0.05)$, which indicates the oysters' affectation by ingesting both elements; concurrently, the results confirm that oysters present high tolerance to heavy metals. The average concentration of cadmium $(2.05 \mu \mathrm{g} / \mathrm{g})$, chromium $(1.82 \mu \mathrm{g} / \mathrm{g})$ and copper $(115.55 \mu \mathrm{g} / \mathrm{g})$ in rainy-season climate exceeded the limits for marine mollusks regarding different health standards. It was found that the rainy season, the sediment characteristics and organic matter content have a great influence on the transport and availability of heavy metals.
\end{abstract}

Keywords Contamination - Heavy metals - Marine sediments · Oyster condition index

C. A. Aguilar $(\square)$ · C. Montalvo · J. G. Cerón · R. M. Cerón Universidad Autónoma del Carmen, Facultad de Ciencias Químicas, Avenida 56 No. 4 entre Avenida Concordia C.P, C.P 24180, Ciudad del Carmen, Campeche, Mexico e-mail: caguilar@pampano.unacar.mx

L. Rodríguez

Instituto Tecnológico de Mérida, División de Estudios de Posgrado e Investigación Av, Tecnológico S/N Km. 4.5, C.P 97118, Mérida, Mexico

\section{Introduction}

Coastal ecosystems are exposed to large amounts of untreated waste products dumped into the waterbodies from industrial and urban activities, thus contributing to the increase of certain contaminants; mainly pesticides, fertilizers and heavy metals (Huang 2003; Cuong et al. 2005; Vane et al. 2009). Particularly, heavy metals are of special interest as they are highly persistent, toxic and have a potential for bioaccumulation in the organisms exposed to them (Shi and Wang 2004). Therefore, they can be present throughout the food chain and may even pass on to humans. Organisms exposed to contamination have different responses which range from modifications in their behavior, physiology or simple tolerance or intolerance to the contaminants.

Given the diverse responses from individuals as well as from populations, a number of mollusks (marine animals) are employed as contamination indicators due to their ability to accumulate contaminants (Baqueiro et al. 2007).

Correspondingly, it is well known that bivalve mollusks are able to survive in the intertidal zone, where they are subject to frequent periods of dryness, salinity and temperature changes, and huge amounts of sediments (Almeida et al. 2003). The tolerance and adaptability of the bivalve mollusks have made them the preferred organisms for monitoring contaminants, and constitute reliable indicators of the quality of given ecosystems (Conti and Cecchetti 2003). However, some physiological factors such as spawning and growth can directly affect their capacity as indicator organisms of contamination, while certain contaminants can affect said factors as well, which underscores the importance of better understanding the dynamics of these physiological processes. 


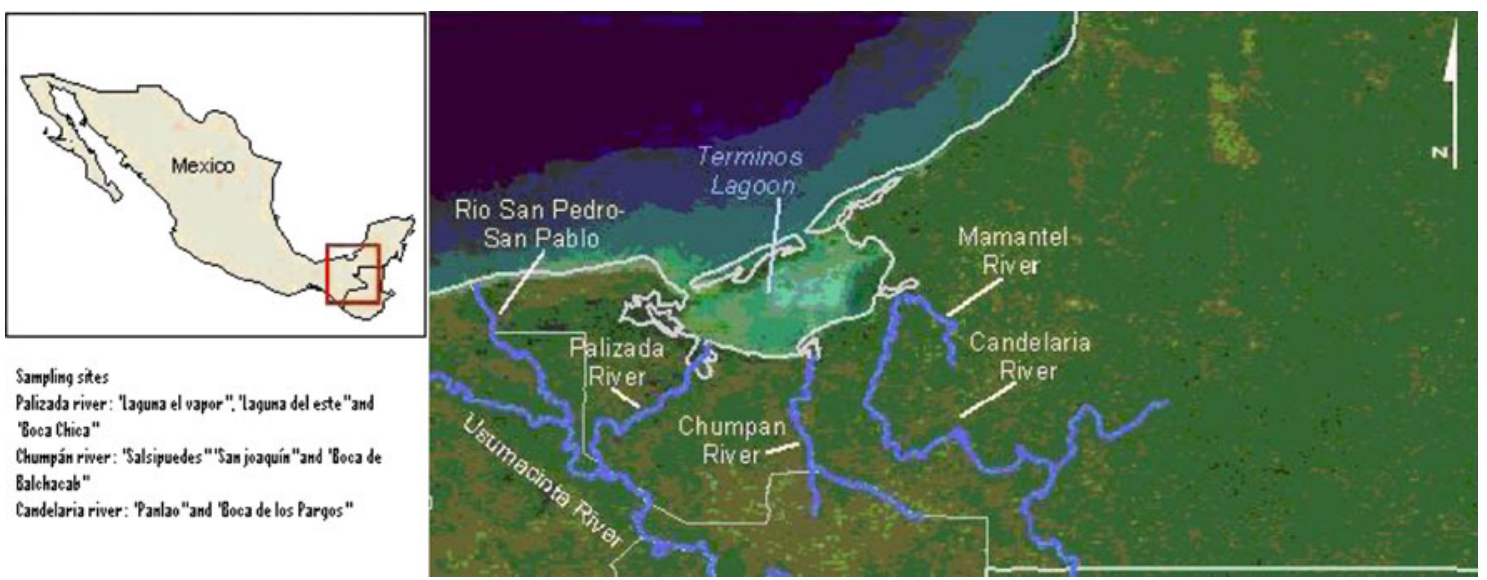

Fig. 1 Study area showing the three sample zones (Palizada, Chumpán and Candelaria rivers) collection of oysters and sediments

Hence, the condition index $(\mathrm{CI})$, is often routinely analyzed to provide estimates of factors such as meat quality in yield. In addition, studies (Scott and Lawrence 1982) have shown that this oyster is affected by a variety of waterborne pollutants (heavy metals, pesticides, organic compounds). Rebelo et al. (2005) has suggested that the condition of these oysters might be used to monitor this pollution.

To measure this physiological parameter, the method suggested by Galtsoff (1964) and Hopkin's standardised formula were used: $\mathrm{CI}=\frac{\mathrm{DMW}_{(\mathrm{g})}}{\mathrm{ICV}} \times 100$ where $\mathrm{DMW}_{(\mathrm{g})}$ is dry meat weight (in $\mathrm{g}$ ) and $\mathrm{ICV}_{\left(\mathrm{cm}^{3}\right)}$ is internal cavity volume in $\mathrm{cm}^{3}$, cavity volumes previously measured chiefly as capacity by water displacement method, may be determined by subtracting the weight in air of the oyster's valves from the weight in air the intact oyster (both in $\mathrm{g}$ ).

On the other hand, the study of sediments enables an integral estimation of an aquatic ecosystem's contamination, since those are the main receptors of most contaminants deposited in the water column by precipitation. Metals associated with the organic fraction can form solutions and become available to the aquatic life forms of a given environment, so it is possible to establish a relation between heavy metals in sediments and living organisms.

Santos et al. (2003) and Lima et al. (2005) showed the importance of sediments as contamination indicators in aquatic environments. Some characteristics such as sediment's grain size and the amount of organic matter are of great importance as they determine the presence and availability of certain contaminants (Suavé et al. 2000). There are different means through which heavy metals are fixed to the sediments in marine ecosystems (Bruder et al. 2002): absorption, co-precipitation with hydroxides and iron oxides, precipitation with organic matter and other natural mechanisms related to the physicochemical characteristics of sediments. Currently the production of oysters has declined significantly and is attributed to the presence of contaminants and diseases.

This study evaluated the levels of various heavy metals in oysters and sediments as well as relations between the factors. It is important to monitor metal concentrations, to detect the source of pollution, and to evaluate the effects on organisms to establish culture areas and adequate criteria for the exploitation of such an important fishery resource.

\section{Materials and methods}

The Terminos Lagoon is located in the Gulf of Mexico (in the protected natural area) and is one of the most studied ecosystems in Mexico due to its importance as the birthplace of numerous species of flora and fauna. Terminos Lagoon is the largest volume lagoon in the Gulf of Mexico, the surface of the lagoon including fluvial systems is approximately $2000 \mathrm{~km}^{2}$ and its area covers 705,016 ha which makes it one of Mexico's largest Natural Protected Areas, as it was declared in 1994 (INE/SEMARNAP 1997). The northern end of the continental platform of the lagoon is highly productive regarding petroleum extraction, and it has been shown that it can be a source of hydrocarbons for the ecosystem (Noreña et al. 1999). Furthermore, tributary rivers such as the Chumpán and the Candelaria flowing into the south of the lagoon are a source of agrochemical products. Likewise, there are a number of interior lagoons, such as the Pom, Atasta, Del Corte, San Carlos, Del Este, Balchacah and Palau. Figure 1 shows the study area.

Two sampling campaigns were conducted during the rainy (January-June) and dry seasons (February-May). Nine sampling stations were set up in three zones. From 
Table 1 Average global concentration of heavy metals (of all sites) in $\mu \mathrm{g} / \mathrm{g}$

\begin{tabular}{|c|c|c|c|c|c|c|c|c|}
\hline & \multicolumn{4}{|c|}{ Sediments $(\mu \mathrm{g} / \mathrm{g})$} & \multicolumn{4}{|c|}{ Oysters $(\mu \mathrm{g} / \mathrm{g})$} \\
\hline & \multicolumn{2}{|c|}{ Dry season } & \multicolumn{2}{|c|}{ Rainy season } & \multicolumn{2}{|c|}{ Dry season } & \multicolumn{2}{|c|}{ Rainy season } \\
\hline & Mean & Range & Mean & Range & Mean & Range & Mean & Range \\
\hline $\mathrm{Ba}$ & 0.86 & $0.60-1.20$ & 0.88 & $0.70-0.90$ & 1.30 & $1.10-1.42$ & 1.92 & $1.10-2.40$ \\
\hline $\mathrm{Cu}$ & 8.17 & $6.4-9.7$ & 18.91 & $11.32-26.14$ & 90.61 & $47.10-164.50$ & 115.55 & $64.00-231.12$ \\
\hline $\mathrm{Cd}$ & 0.24 & $0.20-0.40$ & 0.27 & $0.20-0.40$ & 1.27 & $2.90-4.30$ & 2.05 & $0.40-3.40$ \\
\hline $\mathrm{Cr}$ & 0.40 & $0.30-0.60$ & 0.40 & $0.30-0.40$ & 1.15 & $0.80-1.60$ & 1.82 & $1.20-240$ \\
\hline $\mathrm{Hg}$ & 0.25 & $0.10-0.50$ & 0.47 & $0.30-0.80$ & 0.59 & $0.20-1.00$ & 0.88 & $0.40-2.00$ \\
\hline V & 3.37 & $0.70-4.80$ & 4.40 & $3.30-5.30$ & 1.99 & $0.70-3.60$ & 1.77 & $0.20-3.50$ \\
\hline
\end{tabular}

each station, 100 oysters were taken and their heavy-metal content and condition index were analyzed. Before extracting the tissues from the oysters, they were purged during a 24-h period in a system with controlled salinity of $20 \mathrm{ppm}$. By doing so, the oysters eliminated all organic matters from their intestines which could interfere with the results. Finally, they were shucked manually. On the other hand, samples of superficial sediments were collected at each station using a $0.1 \mathrm{~m}^{3}$ Van Veen grab. All samples of sediments collected were stored in polypropylene containers previously washed in a solution of $10 \% \mathrm{HCl}$ to remove possible traces of contaminants adsorbed to the surface.

\section{Analysis of samples}

Oysters and sediments were dried by means of lyophilisation for $24 \mathrm{~h}$. Later, they were homogenised and treated differently (for the determination of barium, cadmium, chromium, copper, mercury and vanadium). For the dried oyster tissue, a modified technique taken from the proposal in the Manual of the Methods in Aquatic Environment Research was used, which consisted in the acidic digestion of the tissues by the repetitive addition of concentrated $\mathrm{HNO}_{3}$ and $\mathrm{H}_{2} \mathrm{O}_{2}$. Regarding the sediments, they were treated with $1 \mathrm{M}$ of $\mathrm{HCl}$ to extract the bioavailable fraction of the metal. All samples were analysed by optical emission spectroscopy inductively coupled plasma (ICP-OES); with an instrument Perkin-Elmer model 400 and standard solutions (J.T Baker). For the evaluation of the analytical quality, the samples of oyster tissue were treated in duplicate and analysed along with the standard certificates of "standard reference materials oyster tissue" (SRM1566 b), with a recovery percentage between 84 and $94 \%$. Organic matter content in sediments was analysed by oxidation with potassium dichromate and by titration with ferrous sulphate (Gaudette et al. 1974). The analysis of the sediment's texture was carried out by the hydrometric technique based on the Bouyoucos scale as proposed by Buchanan and Kain (1971).

Oyster condition index (CI)

Samples of 30-50 oysters $(5.7-17 \mathrm{~cm})$ were collected from Palizada, Chumpan and Candelaria rivers, for each of these oysters, internal cavity volume was determined by both water displacement and weighing in air techniques. Capacities were measured in a 2,000-ml cylinder with 20-ml graduated increments. A reference level was chosen, the intact oyster or its valves introduced, and the water returned to the reference level by pipeting; cavity capacities in ml were determined by subtracting the two sets of measures for each oyster.

Statistical analysis

The seasonal variations, sampling sites and the type of sample were analysed through an ANOVA test. The relations between heavy-metal concentrations with the condition index, organic matter and sediment's texture were evaluated by means of a correlation analysis. All the statistical tests were conducted at a $95 \%$ confidence level. The data normality was tested by the application of the Shapiro-Wilk test.

\section{Results and discussion}

Heavy metals in oysters and condition index (CI)

Table 1 shows the global average values of the elements detected in Crassostrea virginica and sediments. It can be observed that the oyster bioaccumulates most of the heavy metals mainly during the rainy season.

This tendency could be due to the physiological characteristics of the specie, such as the degree of maturity and 
Table 2 Average concentration of heavy metals (rainy and dry seasons) in areas of study $(\mu \mathrm{g} / \mathrm{g})$ for $C$. virginica

\begin{tabular}{lcrrrrr}
\hline Study areas & $\mathrm{Ba}$ & $\mathrm{Cu}$ & $\mathrm{Cd}$ & $\mathrm{Cr}$ & $\mathrm{Hg}$ & $\mathrm{V}$ \\
\hline Candelaria & 1.6 & 60.5 & 2.4 & 1.4 & 1.1 & 1.3 \\
Chumpán & 1.8 & 90.8 & 3.2 & 1.6 & 0.7 & 2.1 \\
Palizada & 1.5 & 176.5 & 3.0 & 1.5 & 0.5 & 2.0 \\
\hline
\end{tabular}

feeding habits. This is to be considered, since at certain moments, they require an increase in their metabolic rate which results in higher filtration of surrounding water, larger collection of suspended particulate matter, and greater ingestion of heavy metals (Ponce and Botello 1991). Other possible influence on the collection of heavy metals by the $C$. virginica is the mechanisms of atmospheric circulation and transport, the coastal circulation in the area and of the lagoon itself. $\mathrm{Cd}$ and $\mathrm{Cr}$ levels detected in this study are similar to those were previously reported (Villanueva and Vázquez 1992). This could be because in the last 20 years, diverse chemical products used in agriculture and farming have been substituted for less toxic or biodegradable components. However, the maximum levels of $\mathrm{Cu}$ and $\mathrm{Cd}$ detected in C. virginica are higher than those reported by Amat et al. (2002) and Apeti et al. (2005), respectively.

Table 2 shows average concentration of heavy metals in areas of study for $C$. virginica.

It can be observed that the levels of $\mathrm{Cd}$ in the three rivers are higher than those established in the Official Mexican Standard (SSA 1993), which sets a maximum of $0.5 \mu \mathrm{g} / \mathrm{g}$ for marine mollusks and maximum limits established by FAO of $2 \mu \mathrm{g} / \mathrm{g}$ (Nauen 1983). Cadmium did not exceed the limits $(3.7 \mu \mathrm{g} / \mathrm{g})$ set by the FDA (1993).

Similarly, the levels of $\mathrm{Cr}$ surpassed the specifications of FAO limit of $1 \mu \mathrm{g} / \mathrm{g}$ for marine mollusks (Nauen 1983) and below the limit $(13 \mu \mathrm{g} / \mathrm{g})$ that was set by FDA (1993).

Copper is an essential element, but it can be toxic and cause several damages at concentrations beyond the tolerance limits. In this study, the $\mathrm{Cu}$ levels of the Palizada River exceeded the level $(32.5 \mu \mathrm{g} / \mathrm{g})$ set by the FAO (Nauen 1983).

$\mathrm{Hg}$ is one of the metallic elements those are very toxic to living beings. Most organic and inorganic $\mathrm{Hg}$ is associated with organic matter forming sulphur ligands (Villanueva

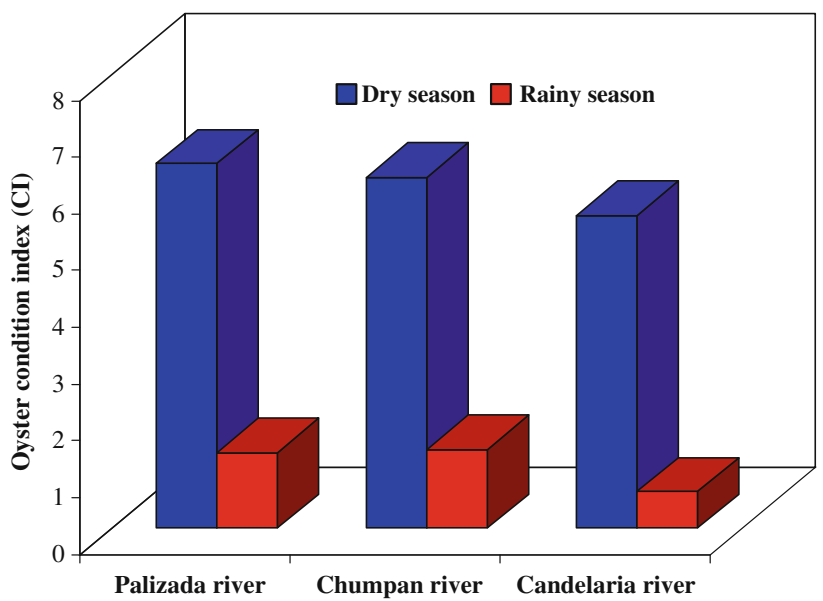

Fig. 2 Behaviour of the oyster condition index during two weather seasons in the three sampling zones

and Vázquez 1992). The rainy season was the most significant in the accumulation of $\mathrm{Hg}$ by $C$. virginica, as these variations are associated with the circulation phenomena, tidal diffusion and other meteorological phenomena. $\mathrm{Hg}$ does not exceed the limits established in the Official Mexican Standard (SSA 1993) which sets a maximum of de $1.0 \mu \mathrm{g} / \mathrm{g}$ for marine mollusks in the Chumpan and Palizada rivers.

The rainy season has a greater influence on the accumulation of $\mathrm{Ba}$ and $\mathrm{V}$. Vanadium is an uncommon heavy metal which has been detected in the sediments of the lagoons in the State of Tabasco (Fiedler et al. 2008), showing a tendency to increase in relation to the depth. The presence of $\mathrm{V}$ and other heavy metals is attributed to the industrial activities related to the exploration of hydrocarbons in the area. Different studies done in nearby areas have also reported $\mathrm{Ni}, \mathrm{Ba}, \mathrm{Cr}, \mathrm{Pb}$ and $\mathrm{Cd}$ (Marín et al. 1997; Vázquez et al. 2002). There are no legal limits for the comparison of $\mathrm{Ba}$ and $\mathrm{V}$ in marine organisms.

An ANOVA test (Table 3) determined that there are significant differences between study areas and weather seasons for $\mathrm{V}, \mathrm{Hg}$ and $\mathrm{Cu}(p<0.05)$.

Cadmium was the only metal that did not show any significant difference for the sampling zones and the weather seasons $(p>0.05)$. The analysis of the multiple comparisons of means indicates that the values of $\mathrm{Cu}$ in the Palizada River showed a significant difference $(p<0.05)$.

Table 3 Values obtained from ANOVA test

\begin{tabular}{lllllll}
\hline Source of variation & $p$ value $(\mathrm{V})$ & $p$ value $(\mathrm{Hg})$ & $p$ value $(\mathrm{Cu})$ & $p$ value $(\mathrm{Cd})$ & $p$ value $(\mathrm{Ba})$ & $p$ value $(\mathrm{Cr})$ \\
\hline Rivers & $0.0498^{* *}$ & $0.0080^{* *}$ & $0.0000^{* *}$ & 0.2433 & 0.2653 & 0.6460 \\
Weather season & $0.0456^{* *}$ & $0.0315^{* *}$ & $0.0146^{* *}$ & 0.0859 & $0.00020^{* *}$ & $0.00120^{* *}$ \\
\hline
\end{tabular}

** Significant value with a confidence level of $95 \%$ 
Table 4 Correlation values between heavy metals and oyster condition index (CI)

\begin{tabular}{lllllll}
\hline Weather season & $\mathrm{Ba}$ & $\mathrm{Cu}$ & $\mathrm{Cd}$ & $\mathrm{Cr}$ & $\mathrm{Hg}$ & $\mathrm{V}$ \\
\hline Dry & -0.454 & -0.382 & -0.321 & $-0.787^{* *}$ & 0.0516 \\
Rainy & 0.727 & $-0.825^{* *}$ & -0.221 & 0.491 & 0.1725 \\
\hline
\end{tabular}

** Significant value with a confidence level of $95 \%$

Table 5 Average percentage of the characteristics of the sediment texture, organic matter (OM) and heavy metals in $\mu \mathrm{g} / \mathrm{g}$ (rainy and dry season) in areas of study

\begin{tabular}{lllllllllll}
\hline Study areas & Sand & Lime & Clay & OM & Ba & $\mathrm{Cu}$ & $\mathrm{Cd}$ & $\mathrm{Cr}$ & $\mathrm{Hg}$ & $\mathrm{V}$ \\
\hline Candelaria River & 77.9 & 18.3 & 4.2 & 22.4 & 0.827 & 12.75 & 0.233 & 0.401 & 0.367 & 4.86 \\
Chumpán River & 73.8 & 20.9 & 5.3 & 13.5 & 0.866 & 14.29 & 0.266 & 0.400 & 0.433 & 4.00 \\
Palizada River & 72 & 23.2 & 5.3 & 20.1 & 0.916 & 13.60 & 0.283 & 0.420 & 0.233 & 4.48 \\
\hline
\end{tabular}

The possible damages caused by the heavy metals to the $C$. virginica were evaluated based on the relations with the CI. Figure 2 shows the results.

The CI (oyster condition index) showed a marked decrease during the rainy season. A multiple-range test confirmed the statistically significant differences $(p<0.05)$ between the CI values found in the Palizada River. The correlation values are shown in Table 4.

Both $\mathrm{Cu}(r=-0.825, p<0.05)$ and $\mathrm{Cr}(r=-0.787$, $p<0.05$ ) have high negative correlations with $\mathrm{CI}$, indicating their contribution in the CI decrease.

Different studies have shown that the damage in C. virginica due to heavy metals in organisms exposed (Shi and Wang 2004; Guzmán et al. 2007), since samples exposed to $\mathrm{Cd}$ clearly showed inflammatory answers: damage to the epithelium of the digestive track, basophilia and hyalinisation. Marín et al. (1997) found significant correlations between $\mathrm{CI}$ and levels of $\mathrm{Cu}(r=-0.652)$. Recently Gold et al. (2007) assessed pollution-related damage in $C$. virginica, obtaining significant values between cholinesterase activities with $\mathrm{Cu}$ and $\mathrm{Cr}$. Cholinesterase activity is a marker of abnormal lipid metabolism. The analysis of their activity is of important to detect cases of poisoning by pesticides and other contaminants. The results confirm the damage to $C$. virginica by the presence of heavy metals, consistent with the results of different studies showing the high affinity of bivalve mollusks with $\mathrm{Cu}, \mathrm{Cd}$ and $\mathrm{Cr}$.

The sediment characteristics are shown in Table 5. Sand fractions were dominated by high percentages (68-79\%), smaller fraction of lime (14-27\%), clay (6-4\%), and high organic matter content (17-25\%), all of which in some way can predispose the presence of heavy metals.

Table 5 shows the average global results of the analysis of heavy metals in sediments during both weather seasons, which presented the following concentration $\mathrm{Cu}>\mathrm{V}>\mathrm{Ba}>\mathrm{Cr}>\mathrm{Hg}>\mathrm{Cd}$. An ANOVA test (Table 6) determined that there are no significant differences in terms of weather seasons and sampling site $(p>0.05)$.

In this study, the heavy metals in sediments are below the ERL (ERL and ERM guideline values for heavy metals that can cause biological effects in marine organisms exposed, which is the method being used as a basis for developing sediment quality guidelines). The incidence of adverse effects increases with increased concentrations of all trace metals. The incidence of adverse effects usually was less than $25 \%$ at concentrations below the ERL values (Long et al. 1995).

These relations were established with the values of the correlation analysis between organic matter, sediment texture and heavy metals, and found significant relations between OM-clay, V-sand, OM-Cu, and Cu-clay (Table 7) The organic-matter content in these zones is usually high, since they are influenced by an extensive area of mangroves, several species of macrophytes (mangrove and sea grasses) and human settlements, which make a substantial contribution to its variability.

Copper showed a high relation with the finest particles of the sediment due to the latter's high specific surface. This offers greater absorption and ionic attraction by the negative charge of the clay particles and organic matter with which $\mathrm{Cu}$ has a close relation. High concentrations of $\mathrm{Cu}$ have been related to wastewater discharges and the way hydrocarbons are handled (González et al. 2006). None of the other analysed metals showed a relation with organic matter. These results suggest that the metals in question are not biogenic, as other studies have pointed out (Wang et al. 2010) as they have found significant values in the relation of $\mathrm{Pb}, \mathrm{Cu}$ and $\mathrm{Cd}$ with organic matter. 
Table 6 Values obtained from ANOVA test

\begin{tabular}{lllllll}
\hline Source of variation & $p$ value $(\mathrm{V})$ & $p$ value $(\mathrm{Hg})$ & $p$ value $(\mathrm{Cu})$ & $p$ value $(\mathrm{Cd})$ & $p$ value $(\mathrm{Ba})$ & $p$ value $(\mathrm{Cr})$ \\
\hline Rivers & 0.174 & 0.3806 & 0.8398 & 0.1959 & 0.8796 & 0.4972 \\
Weather season & 0.1838 & 0.9385 & 0.000 & 0.109 & 0.7971 & 0.8844 \\
\hline
\end{tabular}

Table 7 Values obtained from the analysis of correlation $(r)$ between sediment texture, organic matter and heavy metals

\begin{tabular}{lccccccc}
\hline & Organic matter & $\mathrm{V}$ & $\mathrm{Hg}$ & $\mathrm{Cu}$ & $\mathrm{Cd}$ & $\mathrm{Ba}$ & $\mathrm{Cr}$ \\
\hline Sand & 0.106294 & $0.5113^{* *}$ & -0.3657 & 0.1840 & 0.1623 & 0.0429 \\
Lime & -0.1286 & -0.5504 & 0.3925 & -0.6181 & -0.1030 & 0.004370 \\
Clay & $0.5310^{* *}$ & 0.280085 & -0.14228 & $0.7501^{* *}$ & -0.26542 & -0.19996 \\
OM & & -0.4126 & -0.20399 & $0.4066^{* *}$ & -0.48253 & -0.07248 & 0.01497 \\
& & & & & & 0.008546 \\
\hline
\end{tabular}

** Significant value with a confidence level of $95 \%$

Of all the metals analysed, $\mathrm{Cu}(24.56 \mu \mathrm{g} / \mathrm{g}$ in rainy season) was found in concentrations higher than those reported by Ponce and Botello (1991) and González et al. (1994). High levels of $\mathrm{Cd}(0.40 \mu \mathrm{g} / \mathrm{g})$ were determined in this study. The presence of $\mathrm{Cd}$ in soils is highly correlated with dissolved organic matter due to its easy mobility and transport, as its metal-organic complexes are highly soluble (Li and Zhou 2010). In the study area, agriculture constitutes the main economic activity and it generates large amounts of wastes by the use of fertilizers with high content of Cd (González et al. 2006).

In this study, the highest concentration of $\mathrm{V}$ was detected in the Candelaria River with $5.30 \mu \mathrm{g} / \mathrm{g}$ during the rainy season. Accordingly, different studies have reported significant amounts of $\mathrm{V}, \mathrm{Ni}, \mathrm{Ba}, \mathrm{Cr}, \mathrm{Pb}$ and $\mathrm{Cd}$ (Vázquez et al. 2002; Vázquez and Sharma 2004). Fiedler et al. (2008) attributed the presence of $\mathrm{V}$ to the proximity to the oil-extraction areas in the lagoons of Tabasco.

In the Palizada River, $0.56 \mu \mathrm{g} / \mathrm{g}$ of $\mathrm{Hg}$ was detected in the rainy season. The results of this study are comparable to those determined in the Coatzacoalcos River (Halffter et al. 1973); however, there are no recent studies for an updated comparison. In the marine environment, most organic and inorganic $\mathrm{Hg}$ is associated with particles, colloids and inorganic material constituting sulphur ligands (Wallace et al. 1982); sediments are the primary site for its accumulation (Campbell and Loring 1980).

\section{Conclusion}

The oysters ( $C$. virginica) of the Términos Lagoon have been exposed to large amounts of contaminants that have modified their biological characteristics as different studies have shown. Some heavy metals such as $\mathrm{Cu}$ and $\mathrm{Cr}$ have shown a direct relation with a decrease in the CI, which denotes a possible affectation for these elements. In the same way, the organisms' high tolerance to heavy metals, including their bioaccumulation was found. That is the reason why the heavy metals concentration in the organisms is higher than those found in the sediments. The rainy season has a greater influence on heavy-metal accumulation in organisms, due to the increased flow in the rivers and mudslides from the discharge of the surrounding areas, this season is characterised by heavy rains and winds, unlike the dry season in which no significant rainfall was recorded. Although the levels of some heavy metals in certain places exceed both national and international specifications, there has been no report of any alteration in the health of the population due to the consumption of oysters. Oysters obtain the metallic ions from the water and the suspended particulate material available where they develop. The characteristics of the sediment are fundamental, especially the organic matter, which contained high concentrations in every zone studied. In a certain way, this predisposes the organisms to the bioavailability of these metallic elements, as well as to other contaminants. In this study, the presence of the analysed metals is attributed to human activities, the contribution of tidal movements which transport some of the contaminants, and the influence of rainwater. On the other hand, the levels of heavy metals determined in this study are below ERL values as a reference set to produce biological effects in organisms exposed, for what can be considered that the sediments are suitable for the development of oyster but the potential danger for human consumption due to the biomagnification of contaminants in the body. 
Open Access This article is distributed under the terms of the Creative Commons Attribution License which permits any use, distribution, and reproduction in any medium, provided the original author(s) and the source are credited.

\section{References}

Almeida EA, Bainy AC, Medeiros MH, Di Masio P (2003) Effects of trace metal and exposure to air on serotonin and dopamine levels in tissues of the mussel Perna perna. Mar Pollut Bull 46:14851490

Amat PD, Conde AP, Casals I, Vazquez D (2002) Estudio de la contaminación por metales pesados en sedimentos y ostiones de la Bahia de Manzanillo. Cuba Rev Soc Quim Mex 46(4):357361

Apeti DA, Robinson L, Jhonson E (2005) Relationships between heavy metals concentration in the American oyster (Crassostrea virginica) and metal levels in the water column and sediments in Apalachicola Bay Florida. Am Environ Sci 1:179-186

Baqueiro ER, Borabe L, Goldaracena CG, Rodríguez J (2007) Los moluscos y la contaminación. Revista Mexicana de la Biodiversidad 78:1-7

Bruder HV, Lagarde F, Leroy MJ, Coughanowr C, Enguehard F (2002) Application of a sequential extraction procedure to study the release of elements from municipal solid waste incineration bottom ash. Anal Chim Acta 451:285-295

Buchanan JB, Kain JM (1971) Measurement of the physical and chemical environment. In: Holme NA, Mc Intyre AD (eds) Methods for the study of marine benthos, international biological program handbook no. 16. Blackwell Scientific Publications, Oxford

Campbell JA, Loring DH (1980) Baseline levels of heavy metals in water and sediments of Baffin Bay. Mar Pollut Bull 11:257-261

Conti ME, Cecchetti G (2003) A biomonitoring study: trace metals in algae and molluscs from Tyrrhenian coastal areas. Environ Res 93:99-112

Cuong DT, Bayen S, Wurl O, Subramanian K, Shing KK, Sibasoti N, Obard JP (2005) Heavy metal contamination in mangrove habitats of Singapore. Mar Pollut Bull 50:1732-1738

Fiedler S, Siebe C, Herre A, Roth B, Cram S, Stahr K (2008) Contribution of oil industry activities to environmental loads of heavy metals in the Tabasco Lowlands. Mex Water Air Soil Poll 197(1-4):35-47

Food and Drug Administration (1993) Guidance documents for trace elements in seafood. FDA Guidance documents for arsenic, cadmium, chromium, nickel (January), lead (August). http://www. cfsan.fda.gov

Galtsoff PS (1964) The American oyster Crassostrea virginica Gmelin. Fish Bull 64:1-480

Gaudette HE, Wilson RF, Toner L, Folger DW (1974) An inexpensive titration method for the determination of organic carbon in recent sediments. J Sed Petro 44:249-253

Gold BG, Zápata PO, Ceja MV, Rodríguez FG, Simá AR, Aguirre ML, Vidal MV (2007) Biological effects of environmental pollutants in American oyster, Crassostrea virginica: a field study in Laguna de Términos. Méx Int J Environ Health 1:171184

Gonzaléz A, Vásquez A, Villanueva S, Pónce G (1994) Presencia de metales en sedimentos recientes y organismos de la Laguna de Sontecomapán, Veracruz. Hidrobiológica 4:35-43

González MC, Méndez L, López D, Botello A (2006) Evaluación de la contaminación en sedimentos del área portuaria y zona costera de Salina Cruz Oaxaca, México. Interciencia 31:647-656
Guzmán X, Martínez A, Rodríguez L, González H, Botello A (2007) Cambios tisulares en el ostión Crasostrea virginica por exposición y depuración al cadmio. Hidrobiológica 17:41-44

Halfter GR, Ibarra A, Ochoa A (1973) Estudio de la contaminación en el bajo Río Coatzacoalcos. Informe final. Escuela Nacional de Ciencias Biológicas IPN, México

Huang L, Tan Y, Song X, Huang X, Wang H, Zhang S, Dong J, Chen $R$ (2003) The status of the ecological environment and a proposed protection strategy in Sanya Bay, Hainan Island. China Mar Pollut Bull 47(1-6):180-186

Instituto Nacional de Ecología/Secretaría del Medio Ambiente, Recursos naturales y Pesca (1997) Programa de manejo del Área de Protección de Flora y Fauna Laguna de Términos, INE/ SEMARNAP, México

Li Z, Zhou L (2010) Cadmium transport mediated by soil colloid and dissolved organic matter: a field study. J Environ Sci 22(1): 106-115

Lima CL, Olivares RS, Columbie I, De la Rosa D, Gil CR (2005) Niveles de plomo, zinc, cadmio y cobre en el Río Almendares, Ciudad Habana. Cuba Rev Int Contam Ambient 21(3):115-124

Long ER, Macdonald DD, Sherri LS, Calder FD (1995) Incidence of adverse biological effects within ranges of chemical concentrations in marine and estuarine sediments. Environ Manage 19(1): 81-97

Marín L, Baeza L, Zapata O, Gold G (1997) Trace metals in the American oyster, Crassostrea virginica and sediments from the coastal lagoon Mecoacan, Carmen and Machona, México. Chemosphere 34:2437-2450

Nauen CE (1983) Compilation of legal limits for hazardous substances in fish and fishery products. Food and agriculture Organization of the United Nations, FAO Fisheries No. 764, FIRI/C764

Noreña E, Gold G, Zapata O, Sericano J (1999) Polynuclear aromatic hydrocarbon in American oysters (Crassostrea virginica) from the Términos Lagoon, Campeche, México. Mar Pollut Bull 38:637-645

Ponce G, Botello AV (1991) Aspectos geoquímicos y de contaminación por metales pesados en la Laguna de Términos, Campeche. Hidrobiológica 1:1-10

Rebelo MF, Amaral MC, Pfeiffer WC (2005) Oyster condition index in Crassostrea rhizophorae (Guilding, 1828) from a heavy-metal polluted coastal lagoon. Braz J Biol 65(2):345-351

Santos BJC, Beltrán R, Gómez AJ (2003) Spatial variations of heavy metals contamination in sediments from Odiel River (southwest Spain). Environ Int 29(1):67-77

Sauvé S, Hendershot W, Allen HE (2000) Solid-solution partitioning of metals in contaminated soils: dependence of $\mathrm{pH}$, total metal burden and organic matter. Environ Sci Tech 34(7):1125-1131

Scout GI, Lawrence DR (1982) The American oyster as a coastal zone pollution monitor: a pilot study. Estuaries 5:27-33

Shi D, Wang WX (2004) Understanding the differences in Cd and Zn bioaccumulation and subcellular storage among different populations of marine clams. Environ Sci Tech 38(2):449-456

SSA (1993) Norma Oficial Mexicana NOM-031-SSA1-1993. Límites máximos permisibles de contaminantes para productos de la pesca como moluscos bivalvos frescos y refrigerados. Secretaría de salud, Diario Oficial de la Federación, March 6, 1995

Vane CH, Harrison I, Kim AW, Moss HV, Vickers BP, Hong K (2009) Organic and metal contamination in surface mangrove sediments of south China. Mar Pollut Bull 58:134-144

Vázquez FG, Sharma VK (2004) Major and trace elements in sediments of the Campeche Sound, Southeast Gulf of México. Mar Pollut Bull 48:87-90

Vázquez FG, Sharma VK, Pérez C (2002) Concentration of elements and metals in sediments of the Southeastern Gulf of México. Environ Geol 42:41-46 
Villanueva S, Vázquez A (1992) Metales pesados en la zona costera del Golfo de México y Caribe Mexicano: una revisión. Rev Int Contam Ambient 8(1):47-61

Wallace GT, Seibert DL, Holzknech SM, Thomas WH (1982) The biogeochemical fate and toxicity of mercury in controlled experimental ecosystems. Estuar Coast Shelf Sci 15:151-182
Wang SJ, Wang S, Wang X, Wang H, Zhao Z, Liu B (2010) Fractionation of heavy metals in shallow marine sediments from Jinzhou Bay. Chin J Environ Sci 22(1):23-31 